\title{
Ocular manifestations of occupational exposure to corticosteroids in the pharmaceutical industry
}

\author{
F. M. Metwally ${ }^{1}$, S. El-Assal ${ }^{2}$ \& E. A. Kamel ${ }^{3}$ \\ ${ }^{1}$ Department of Occupational Health and Industrial Medicine, \\ National Research Center, Dokki, Cairo, Egypt \\ ${ }^{2}$ Memorial Institute of Ophthalmology, MOHP, Giza, Egypt \\ ${ }^{3}$ Department of Community Medicine, Mansoura University, \\ Mansoura, Egypt
}

\section{Abstract}

The therapeutic use of corticosteroids has long been associated with ocular side effects such as the development of cataracts, glaucoma, and retinal and choroidal emboli. This study was conducted to assess ocular disorders, which may occur in workers engaged in manufacturing corticosteroids in the pharmaceutical industry. The study population included 58 workers involved in the manufacturing of corticosteroid preparations. They were subdivided according to duration of exposure into 2 groups: Gr. I of $<15$ years duration of employment and Gr. II of 15 + years duration of employment. Methods included answering a structured questionnaire enquiring about occupational and medical histories, full ocular and clinical examination, and measurement of certain biochemical parameters, such as plasma cortisol, serum total cholesterol, serum triglycerides, fasting blood sugar and serum calcium. Results showed that 25 cataracts were diagnosed in the studied group with a rate of 21.55 per one hundred eyes. Of Gr.II, $43.75 \%$ of eyes had cataracts compared to $5.88 \%$ of Gr.I. Odds ratio to develop cataracts was 12.44 for Gr. II compared to Gr.I. Ocular hypertension and open-angle glaucoma were present in $25.00 \%$ of the eyes of the studied groups with odds of 5.83 times more when being employed for 15 or more years. Significant + ve correlation was found between intraocular pressure and relevant biochemical parameters. In the present study, a clear relationship was detected between the length of the period of exposure to corticosteroids as environmental pollutants and the development of ocular medical disorders such as cataracts, ocular hypertension and glaucoma. Further research work is needed to study the effects of exposure to corticosteroids as pollutants in the work environment, gaining access into body via unusual routes of entry, and for periods of time not reported in the therapeutic literature.

Keywords: corticosteroid, ocular manifestations, cataracts, glaucoma, ocular hypertension, occupational, hypertension, diabetes mellitus, lipid profile, pharmaceutical. 


\section{Introduction}

Corticosteroids are widely prescribed in everyday medical practice for the therapy of a vast array of systemic and organ disorders. The risk of occurrence of side effects due to the therapeutic use of corticosteroids is proportional to the dosage and duration of therapy. Topical, oral, and intravenous corticosteroids have long been associated with ocular side effects as the development of cataracts, glaucoma, and retinal and choroidal emboli. Data reported by Carnahan and Goldstein [1] suggested that inhaled corticosteroids were associated with the development of cataracts and increased intraocular pressure (IOP). Haimovici et al. [6] claimed that central serous chorioretinopathy may be associated with inhaled or intranasal corticosteroids. Mitchel et al. [9] found an association between ever use of inhaled corticosteroids and a finding of elevated IOP or glaucoma in subjects with glaucoma family history.

The widespread use of corticosteroids as therapeutics necessitates that the pharmaceutical industries manufacture them in quantities and in preparations that parallel the increasing market demands. Workers involved in the manufacturing processes are inevitably exposed to corticosteroids for periods of time and in concentrations which may mimic long term therapeutic use. Routes of entry of corticosteroids as environmental pollutants may include inhalation of respirable dust suspended in the work atmosphere and absorption through respiratory mucus membrane into blood, direct ocular absorption of soluble dust deposited on conjunctival mucosae, ingestion of dust while eating or smoking with contaminated hands at the workplace, and skin absorption of traces of ointments or creams which may be deposited on the uncovered skin. Cumulative exposure to such an environmental pollutant may lead to long-term consequences on the health of the susceptible individuals. Few, if any studies, discussed ocular and other complications resulting from daily exposure to corticosteroids as environmental contaminants in industry. So, the objective of the present work was to examine the association between the period of occupational exposure to corticosteroids as pollutants in a manufacturing plant and the possible development of ocular and other complications among the exposed workers.

\section{Subjects and methods}

\subsection{The study population}

The study population included 58 workers involved in the manufacturing of corticosteroid preparations in the pharmaceutical industries. Both male and female workers were included in the study. No age or duration of employment was exempt. None of the workers reported any of the systemic diseases or local conditions necessitating prolonged use of corticosteroids as therapeutics. The studied workers were grouped into 2 groups: Gr.I of $(<15)$ years' duration of employment and Gr.II of $(15+)$ years' duration of employment. 


\subsection{Job and workplace description}

The flowchart of the industrial process included the following sections:

A- Storage of raw material which took place in a separate location away from the manufacturing process. Raw materials were composed of powder of fluocortolone and difluocortolone. After weighing the desired amount, the powder was carried manually to the following sections.

B- The preparation unit which included preparation of the following:

I- Ointments and creams:- by using the 'wet granulation method' by mixing about $10 \mathrm{~kg}$ of water with $100 \mathrm{gm}$ of powder in open stainless steel pans 'mills' where mixing was done manually till a colloidal suspension was formed. Then the suspension was transferred into a stainless steel mixer which was operated for one hour. The resulting mixture was then emptied into tanks. Vaseline or paraffin was then added to get the desired texture. Mixing was done manually. The mixture was then emptied into 'hoover tubes' for automatic filling .

II- Ampoules:- which involved heating of a mixture of water and powder in open containers followed by filling of ampoules and sealing using heat. Sterilization in autoclave then followed.

$\mathrm{C}$ - The packaging and labeling of products then the despatching of final product.

The whole process was open with minimal enclosure, if any. The preparation unit was a room of $4 \mathrm{~m} \mathrm{X} 6 \mathrm{~m}$ leading to a lengthy rectangular hall with partitions, of $15 \mathrm{mX} 5 \mathrm{~m}$ in dimension. No exhaust ventilation was present. No protective equipment was used. Inhalation of dust and contact of dust with eyes or skin took place during the transport of raw material and the preparation of the products.

Workers rotated through various sections of production. They were equally exposed to the same pollutants in the work atmosphere.

\section{Methods}

Each participant in the study was subjected to:

- Full medical and occupational history taking with emphasis on probable side effects of corticosteroids.

- Ocular examination that included:

- Full ophthalmological examination.

- IOP measurement in $\mathrm{mm} \mathrm{Hg}$ by applanation tonometry.

- Assessment of visual fields with automated perimetry ( Humphrey 76 point suprathreshold screening test). Glaucoma was diagnosed by the finding of matching optic disc cupping and disc rim thinning (cup-disc ratio $\geq 0.7$ or cupdisc asymmetry $\geq 0.3$ ) plus characteristic visual field defects on automated perimetry.

- Biochemical parameters measurement which included: Plasma cortisol measured by radioimmunoassay, Serum total cholesterol, Serum triglycerides, Fasting blood sugar and Serum calcium.

- Statistical analysis of data was performed using SPSS package version 10.00 and EPI info package version 6.00. 


\section{Results}

The mean age of the whole group was found to be $38.00 \pm 11.97$ years. Females had a mean age of $42.62 \pm 11.65$ years, while males had a mean age $32.30 \pm 9.86$ years. The age difference between females and males was statistically significant. All age groups were represented in the studied group with age ranging from 19 years up to 58 years.

Table 1: $\quad$ Age distribution of the exposed workers.

\begin{tabular}{|c|c|c|c|c|c|c|}
\hline \multirow[t]{2}{*}{ Age Group in Ys } & \multicolumn{2}{|c|}{ Females $(n=32)$} & \multicolumn{2}{|c|}{$\operatorname{Males}(n=26)$} & \multicolumn{2}{|c|}{ All $(n=58)$} \\
\hline & No. & $\%$ & & $\%$ & & $\%$ \\
\hline$<25$ & 2 & 6.25 & 4 & 15.38 & 6 & 10.34 \\
\hline $25-<30$ & 6 & 18.75 & 12 & 46.15 & 18 & 31.03 \\
\hline $30-<40$ & 2 & 6.25 & 4 & 15.38 & 6 & 10.34 \\
\hline $40-<50$ & 14 & 43.75 & 4 & 15.38 & 18 & 31.03 \\
\hline $50+$ & 8 & 25.00 & 2 & 7.69 & 10 & 17.24 \\
\hline Mean (SD) & \multicolumn{2}{|c|}{$42.62(11.65)$} & \multicolumn{2}{|c|}{$32.30(9.86)$} & \multicolumn{2}{|c|}{38.00 (11.97) } \\
\hline Median & \multicolumn{2}{|c|}{46.50} & \multicolumn{2}{|c|}{29.00} & \multicolumn{2}{|c|}{34.00} \\
\hline Min. - Max. & $21-$ & & & 53 & 19 & \\
\hline t-test, $p$-value & \multicolumn{4}{|c|}{$3.58(\mathrm{df} 56), \quad \mathrm{P}<0.01$} & & \\
\hline
\end{tabular}

Table 2: $\quad$ Distribution of the exposed workers by duration of employment.

\begin{tabular}{|c|c|c|c|}
\hline $\begin{array}{l}\text { Duration of } \\
\text { Employment } \\
\text { Group in Years }\end{array}$ & $\begin{array}{l}\text { Females } \\
(n=32) \\
\text { No. }\end{array}$ & $\begin{array}{l}\text { Males } \\
(n=26) \\
\text { No. }\end{array}$ & $\begin{array}{l}\text { All Group } \\
(n=58) \\
\text { No. }\end{array}$ \\
\hline$<5$ & 25.00 & $\begin{array}{ll}4 & 15.38\end{array}$ & $\begin{array}{ll}12 & 20.68\end{array}$ \\
\hline $5-<15$ & 26.08 & 61.53 & 37.93 \\
\hline $15-<25$ & 0.00 & 15.38 & 6.89 \\
\hline $25+$ & 56.25 & 7.69 & 34.48 \\
\hline Mean (SD) & $20.43(14.60)$ & $9.76(7.70)$ & $15.65(13.06)$ \\
\hline Median & 26.50 & 8.00 & 10.00 \\
\hline Min. - Max. & $1-38$ & $0.5-28$ & $0.5-38$ \\
\hline t-test, $\mathrm{p}$-value & 3.36 (df 56), & $P<0.01$ & \\
\hline
\end{tabular}

Mean duration of employment for the whole group was $15.65 \pm 13.06$ years, ranging from 0.5 years up to 38 years. Females had a mean duration of employment of $20.43 \pm 14.60$ years. While for males, the mean was $9.76 \pm 7.70$ years. The difference was statistically significant. Fifty six point twenty five per cent of females were employed for 25 years or more, compared to 7.69 per cent of males. All duration of employment groups were represented in the studied group. 
Table 3: Distribution of the ocular manifestations among the exposed groups $(n=58$ workers, 116 eyes $)$.

\begin{tabular}{|c|c|c|c|}
\hline $\begin{array}{l}\text { Ocular } \\
\text { Manifestation }\end{array}$ & $\begin{array}{l}\text { Group I } \\
(<15 \text { Ys }) \\
\text { (n=68 eyes) } \\
\text { No. \% }\end{array}$ & $\begin{array}{l}\text { Group II } \\
(15+\text { Ys }) \\
(n=48 \text { eyes }) \\
\text { No. } \%\end{array}$ & $\begin{array}{l}\text { All Group } \\
\begin{array}{lr}\text { (n= } & 116 \text { eyes) } \\
\text { No. } & \%\end{array}\end{array}$ \\
\hline $\begin{array}{l}\text { Cataract } \\
\text {-Diagnosed } \\
\text { - Extracted }\end{array}$ & $\begin{array}{cc}4 & 5.88 \\
0 & 0.00\end{array}$ & $\begin{array}{cc}12 & 25.00 \\
9 & 18.75\end{array}$ & $\begin{array}{r}13.79 \\
7.75\end{array}$ \\
\hline - Total & 5.88 & 2143.75 & 21.55 \\
\hline Odds ratio & \multicolumn{3}{|c|}{$12.44(3.56<0 R<47.0), \quad P<0.001$} \\
\hline Ocular Hypert. & $8 \quad 11.76$ & $12 \quad 25.00$ & $20 \quad 17.24$ \\
\hline $\begin{array}{l}\text { Open-angle } \\
\text { Glaucoma }\end{array}$ & $\mathbf{0 . 0 0}$ & 18.74 & 7.75 \\
\hline Total & 11.76 & 43.75 & 25.00 \\
\hline Odds ratio & \multicolumn{3}{|c|}{$5.83(2.11<\mathrm{OR}<16.56), \quad \mathrm{P}<0.001$} \\
\hline
\end{tabular}

Twenty five cataracts were diagnosed in the studied group with a rate of 21.55 per one hundred eyes. Of Gr.II, $43.75 \%$ of eyes had cataracts compared to $5.88 \%$ of Gr.I. The Odds Ratio which is an estimate of the relative risk for eyes to acquire cataracts when being employed for 15 years or more in the manufacturing of corticosteroids was 12.44 times more than the risk when being employed for less than 15 years, i.e., the probability to develop cataracts when being employed for 15 years or more was 12 times more than the probability to develop it when being employed for $<15$ years. Ocular hypertension and open angle glaucoma were present in $25.00 \%$ of eyes of the studied groups with odds of 5.83 times more when being employed for $15+$ years.

Table 4: Distribution of IOP among the exposed groups.

\begin{tabular}{|c|c|c|c|c|c|}
\hline \multirow[t]{2}{*}{ IOP in $\mathrm{mm} \mathrm{Hg}$} & $\begin{array}{l}\text { Group I } \\
(n=68 \text { eyes) }\end{array}$ & \multicolumn{2}{|c|}{$\begin{array}{l}\text { Group II } \\
(n=48 \text { eyes })\end{array}$} & \multicolumn{2}{|c|}{$\begin{array}{l}\text { All Group } \\
\text { (n=116 eyes) }\end{array}$} \\
\hline & No. $\%$ & & $\%$ & No. & $\%$ \\
\hline $10-<15$ & 50.00 & 12 & 25.00 & 46 & 39.65 \\
\hline $15-<20$ & 41.17 & 10 & 20.83 & 38 & 32.75 \\
\hline $20-<25$ & 8.82 & 14 & 29.16 & 20 & 17.24 \\
\hline $25+$ & $\begin{array}{ll}0 & 0.00 \\
\end{array}$ & 12 & 25.00 & 12 & 10.34 \\
\hline Mean (SD) & $14.91(3.31)$ & \multicolumn{2}{|c|}{$19.66(5.16)$} & \multicolumn{2}{|c|}{$16.87(4.78)$} \\
\hline Median & & & & 16 & \\
\hline Min. - Max. & & & & 10 & \\
\hline $\begin{array}{l}\text { t- test (df 114), } \\
\text { P-value }\end{array}$ & -6.03 & & & & \\
\hline
\end{tabular}

Mean IOP differed significantly between Gr.I and Gr.II exposed groups with Gr.II showing higher IOP of $19.66 \pm 5.16 \mathrm{~mm} \mathrm{Hg}$. The mean IOP for the whole group was $16.87 \pm 4.78 \mathrm{~mm} \mathrm{Hg}$. 
Table 5: Mean values of biochemical parameters among the exposed groups.

\begin{tabular}{|c|c|c|c|}
\hline Parameter & $\begin{array}{l}\text { Group I } \\
(n=34) \\
\text { Mean } \pm \text { SD }\end{array}$ & $\begin{array}{l}\text { Group II } \\
(n=24) \\
\text { Mean } \pm \text { SD }\end{array}$ & $\begin{array}{l}\text { All Group } \\
(n=58) \\
\text { Mean } \pm \text { SD }\end{array}$ \\
\hline $\begin{array}{l}\text { Plasma Cortisol: } \\
\text { (Normal: 8.5- } 13.5 \mathrm{ug} / \mathrm{dL} \text { ) }\end{array}$ & $13.48 \pm 1.75$ & $15.54 \pm 0.67$ & $14.33 \pm 1.73$ \\
\hline t-test, P-value & \multicolumn{2}{|c|}{$-5.45,<0.001$} & \\
\hline $\begin{array}{l}\text { Serum total Cholesterol : } \\
\text { (Normal : } 140-270 \mathrm{mg} / \mathrm{dL})\end{array}$ & $206.70 \pm 23.29$ & $262.16 \pm 11.35$ & $229.65 \pm 33.54$ \\
\hline t-test, P-value & \multicolumn{2}{|c|}{$-10.77,<0.001$} & \\
\hline $\begin{array}{l}\text { Serum triglycerides: } \\
(\text { Normal : } 40-140 \mathrm{mg} / \mathrm{dL})\end{array}$ & $138.41 \pm 10.72$ & $155.91 \pm 4.24$ & $145.65 \pm 12.22$ \\
\hline t-test, P-value & \multicolumn{2}{|c|}{$-7.57,<0.001$} & \\
\hline $\begin{array}{l}\text { Fasting blood sugar: } \\
\text { (Normal : } 70-100 \mathrm{mg} / \mathrm{dL})\end{array}$ & $119.64 \pm 17.02$ & $172.16 \pm 19.00$ & $141.37 \pm 31.53$ \\
\hline t-test, P-value & \multicolumn{2}{|c|}{$-11.03,<0.001$} & \\
\hline $\begin{array}{l}\text { Serum calcium } \mathrm{Ca}^{++} \\
\text {(Normal: } 9-11 \mathrm{mg} / \mathrm{dL})\end{array}$ & $8.90 \pm 1.29$ & $6.87 \pm 1.30$ & $8.06 \pm 1.63$ \\
\hline t-test, P-value & \multicolumn{2}{|c|}{$5.87,<0.001$} & \\
\hline
\end{tabular}

The two groups differed significantly in the mean values of the biochemical parameters with Gr.II showing higher values than Gr.I. The mean plasma cortisol for the whole group was $14.33 \pm 1.73 \mathrm{ug} / \mathrm{dL}$ which is higher than the upper limit value of the normal range for this parameter.

Table 6: Relation between biochemical parameters and IOP of the exposed groups.

\begin{tabular}{|l|l|}
\hline Biochemical Parameter & IOP $(\mathbf{n}=\mathbf{1 1 6}$ eyes) $\mathbf{r}$ \\
\hline Plasma cortisol & $0.491^{* *}$ \\
\hline Fasting blood sugar & $0.346^{*}$ \\
\hline Serum triglycerides & $0.391 *$ \\
\hline Serum total cholesterol & $0.392^{*}$ \\
\hline Serum calcium, ca ${ }^{++}$ & -0.47 \\
\hline Age (Ys) & $0.493 * *$ \\
\hline Duration of exposure (Ys) & $0.491 * *$ \\
\hline
\end{tabular}

** Correlation is significant at $\mathrm{P}$-value $<0.01$ (2-tailed).

* Correlation is significant at P-value $<0.05$ (2-tailed).

Significant positive correlation was found between IOP of eyes of the exposed groups and relevant biochemical parameters, especially with plasma cortisol i.e., IOP increases with increase in plasma cortisol. 
Table 7: Distribution of medical disorders among the exposed groups.

\begin{tabular}{|c|c|c|c|c|c|}
\hline \multirow[t]{2}{*}{ Medical disorder } & \multicolumn{2}{|c|}{ Group I $(n=34)$} & \multicolumn{2}{|c|}{ Group II $(n=24)$} & \multirow{2}{*}{$\begin{array}{l}\text { Chi-square, } \\
\text { P-value }\end{array}$} \\
\hline & & & & $\%$ & \\
\hline $\begin{array}{l}\text { Endocrinological: } \\
\text { Weight gain }\end{array}$ & 22 & 64.70 & 18 & 75.00 & $0.67, \mathrm{P}>0.05$ \\
\hline $\begin{array}{l}\text { Diabetes M. under } \\
\text { treatment }\end{array}$ & 0 & 0.00 & 7 & 29.16 & \\
\hline Acne & 16 & 47.05 & 6 & 25.00 & $2.90, \mathrm{P}>0.05$ \\
\hline $\begin{array}{l}\text { Immunological: } \\
\text { Recurrent infections: } \\
\text { Chest infections } \\
\text { Herpes zoster } \\
\text { Fungal infections } \\
\end{array}$ & $\begin{array}{l}14 \\
0 \\
0\end{array}$ & $\begin{array}{c}41.17 \\
0.00 \\
0.00 \\
\end{array}$ & $\begin{array}{l}6 \\
0 \\
0 \\
\end{array}$ & $\begin{array}{r}25.00 \\
0.00 \\
0.00 \\
\end{array}$ & $1.63, \mathrm{P}>0.05$ \\
\hline $\begin{array}{l}\text { Gastrointestinal: } \\
\text { Hyperacidity }\end{array}$ & 22 & 64.70 & 16 & 66.66 & $0.02, \mathrm{P}>0.05$ \\
\hline Increased appetite & 10 & 29.41 & 4 & 16.66 & $1.24, \mathrm{P}>0.05$ \\
\hline $\begin{array}{l}\text { Musculoskeletal: } \\
\text { Bone aches }\end{array}$ & 8 & 23.52 & 20 & 83.33 & $20.15, \mathrm{P}<0.001$ \\
\hline Easy fatiguability & 0 & 0.00 & 4 & 16.66 & \\
\hline $\begin{array}{l}\text { Reproductive: } \\
\text { Menstrual } \\
\text { disturbances: } \\
\text { Amenorrhea } \\
\text { Irregular menses } \\
\text { Early menopause } \\
\end{array}$ & $\begin{array}{l}0 \\
4 \\
0\end{array}$ & $\begin{array}{r}0.00 \\
11.76 \\
0.00\end{array}$ & $\begin{array}{l}2 \\
0 \\
8\end{array}$ & $\begin{array}{c}8.33 \\
0.00 \\
33.33\end{array}$ & \\
\hline $\begin{array}{l}\text { Cardiovascular: } \\
\text { Hypertension under } \\
\text { treatment }\end{array}$ & 2 & 5.88 & 10 & 41.66 & $10.97, \mathrm{P}<0.01$ \\
\hline $\begin{array}{l}\text { Hypertension } \\
\text { (currently Diagnosed } \\
\text { on Clinical ex.) }\end{array}$ & 2 & 5.88 & 10 & 41.66 & \\
\hline Total Hypertension & 4 & 11.76 & 20 & 83.33 & $29.7, P<0.001$ \\
\hline $\begin{array}{l}\text { Thrombo-embolic } \\
\text { phenomenon }\end{array}$ & 0 & 0.00 & 0 & 0.00 & \\
\hline Arrhythmia & 0 & 0.00 & 4 & 16.66 & \\
\hline $\begin{array}{l}\text { Neurological sym.: } \\
\text { Recurrent headaches }\end{array}$ & 18 & 52.94 & 8 & 33.33 & $2.18, \mathrm{P}>0.05$ \\
\hline Migrainous attacks & 4 & 11.76 & 0 & 0.00 & \\
\hline
\end{tabular}

Hypertension was prevalent in $41.37 \%$ of the studied groups, in $83.33 \%$ of Gr.II subjects and in $11.76 \%$ of Gr.I subjects with the difference being statistically significant. Diabetes Mellitus was present in $29.16 \%$ of Gr.II subjects. Hyperacidity was present in about $60 \%$ of either groups. Bone aches were reported by $83.33 \%$ of Gr.II, with a statistically significant difference 
compared to Gr.I. Recurrent headaches were complained of by half of Gr.I and one third of Gr.II.

Table 8(A): Comparison of cases of ocular hypertension and open-angle glaucoma with subjects with normal IOP.

\begin{tabular}{|l|l|l|l|}
\hline Item & $\begin{array}{l}\text { Cases } \\
(\mathbf{n = 1 5}) \\
\text { Mean } \pm \text { SD }\end{array}$ & $\begin{array}{l}\text { Subjects with } \\
\text { normal IOP }(\mathbf{n}= \\
\text { 43 Mean } \pm \text { SD }\end{array}$ & $\begin{array}{l}\text { t- test }(\mathbf{d f}=\mathbf{5 6}), \\
\text { P- value }\end{array}$ \\
\hline Age & $48.12 \pm 6.43$ & $34.14 \pm 11.35$ & $6.07, \quad \mathrm{P}<0.001$ \\
\hline Duration of job & $24.00 \pm 10.54$ & $12.47 \pm 12.61$ & $5.19, \quad \mathrm{P}<0.001$ \\
\hline Plasma cortisol & $15.72 \pm 0.59$ & $13.80 \pm 1.73$ & $4.28, \quad \mathrm{P}<0.001$ \\
\hline Fasting bl. sugar & $161.62 \pm 21.87$ & $133.66 \pm 31.40$ & $3.91, \quad \mathrm{P}<0.001$ \\
\hline
\end{tabular}

Table 8(B): Age distribution of cases of ocular hypertension and open-angle glaucoma $(n=15)$.

\begin{tabular}{|l|l|l|l|l|l|l|l|l|}
\hline Age & 34 Ys & 45 Ys & 48 Ys & 52 Ys & 53 Ys & 55 Ys & 56 Ys & 58 Ys \\
\hline No. & 1 & 2 & 2 & 2 & 2 & 2 & 2 & 2 \\
\hline$\%$ & 6.66 & 13.33 & 13.33 & 13.33 & 13.33 & 13.33 & 13.33 & 13.33 \\
\hline
\end{tabular}

Table 8(A) shows that cases of ocular hypertension and glaucoma among the exposed groups were older, with more years of employment, higher plasma cortisol and fasting blood sugar. Table 8(B) shows that the distribution of age of cases included ages as young as 34 years, 45 years and 48 years. Meanwhile, no family history of glaucoma was reported by participants in the study.

Table 9(A): Comparison of cases of cataracts with subjects not suffering from cataracts.

\begin{tabular}{|c|c|c|c|}
\hline Item & $\begin{array}{l}\text { Cataract cases } \\
(n=16) \\
\text { Mean } \pm \text { SD }\end{array}$ & $\begin{array}{l}\text { Other Subjects } \\
(n=42) \\
\text { Mean } \pm \text { SD }\end{array}$ & $\begin{array}{l}\text { t-test }(\mathrm{df}=56), \\
\text { P-value }\end{array}$ \\
\hline Age & $48.12 \pm 6.43$ & $34.14 \pm 11.35$ & $4.63, \quad \mathrm{P}<0.001$ \\
\hline Duration of job & $24.00 \pm 10.54$ & $12.47 \pm 12.61$ & $3.24, \quad \mathrm{P}<0.01$ \\
\hline Plasma cortisol & $15.72 \pm 0.59$ & $13.80 \pm 1.73$ & $4.30, \quad \mathrm{P}<0.001$ \\
\hline $\begin{array}{l}\text { Fasting bl. } \\
\text { Sugar }\end{array}$ & $161.62 \pm 21.87$ & $133.66 \pm 31.40$ & $3.26, \quad \mathrm{P}<0.01$ \\
\hline
\end{tabular}

Table 9(B): Age distribution of cases of cataracts.

\begin{tabular}{|l|l|l|l|l|l|l|l|}
\hline Age & $\mathbf{3 4}$ Ys & $\mathbf{4 5}$ Ys & $\mathbf{4 8}$ Ys & $\mathbf{4 9}$ Ys & 52 Ys & 53 Ys & 56 Ys \\
\hline No. & 2 & 2 & 4 & 2 & 2 & 2 & 2 \\
\hline$\%$ & 12.5 & 12.5 & 25.00 & 12.5 & 12.5 & 12.5 & 12.5 \\
\hline
\end{tabular}


Table 9(A) shows that cases of cataracts differed from other subjects in age, duration of employment, plasma cortisol and fasting blood sugar. Age of cataract cases started from 34 years onwards which is considered unusually young for cataracts to develop.

\section{Discussion}

In the present study, a clear relationship was detected between the length of the period of exposure to corticosteroids as environmental pollutants and the development of ocular medical disorders such as cataracts, ocular hypertension and open-angle glaucoma. The prevalence of these ocular disorders among the exposed groups exceeded that among the general population and the patients using corticosteroids as therapeutics (Khan et al. [7], Leske et al. [8] and Carnahan and Goldstein [1]).

The occupational exposure to corticosteroids as air pollutants may mimic the therapeutic use of inhalants and nasal preparations, with limitations. Also, direct ocular exposure to dust containing corticosteroids may mimic the therapeutic use of ophthalmic preparations. The prevalence of cataracts in the present study was $21.55 \%$ and it affected workers as young as 34 years. True prevalence of cataracts among the general population is obscure. The Framingham Eye study reported a prevalence of cataracts of $18 \%$ among persons older than 65 years of age. The prevalence of cataracts among the adult population of both sexes of the outpatient clinics and the inpatients of the Memorial ophthalmology Institute of MOHP at Giza was calculated to be $4.74 \%$ in a 6-month period. The prevalence of cataracts among the studied groups can be attributed to the excess exposure to corticosteroids as environmental pollutants in their work atmosphere as evidenced by the higher plasma cortisol in their sera. The use of corticosteroids by nasal spray and inhalation has been associated with the development of posterior subcapsular cataracts as reported by Fraunfelder and Meyer [4]. Garbe et al. [5] similarly concluded that prolonged administration of high doses of inhaled corticosteroids increases the likelihood of undergoing cataract extraction in elderly patients. They found out that the odds ratio for cataract extraction in patients with prolonged cumulative exposure to inhaled corticosteroids compared with non-users was 3.40. Other risk factors may have been operating as well, like exposure to ultraviolet rays and diabetes mellitus. Risk factors together with the occupational exposure to corticosteroids pollutants were mostly responsible for the development of cataracts in the susceptible $20 \%$ of workers and at an earlier age than noticed among the general population as observed by Khan et al. [7], West [13], and Leske et al. [8].

The ocular hypertensive response to intravenous, oral, topical dermatologic, topical ocular, and periocular corticosteroids has been well established by investigators since the 1960s (Dryer [3] and Opatowsky et al. [11]). Increased IOP and odds of developing glaucoma in the studied groups signify that corticosteroids as pollutants in the work atmosphere reach ocular structures in levels sufficient to provoke an ocular hypertensive response in susceptible individuals. 
Systemic absorption of $50 \%$ or more of steroids administered by nasal spray has been documented by the United States Pharmacopeial Convention [12]. Studies have shown that $90 \%$ of aerosol deposition is present in the oropharyngeal, mucosa where the drug could be systemically absorbed as reported by Davies [2] and Newman et al. [10]. Other possible routes of entry and absorption include droplet deposition on the ocular surface, ingestion with absorption from the gastrointestinal tract or inhalation of the nasal spray. The same pattern of routes of entry can be extrapolated to the occupational exposure to corticosteroid dust as an environmental pollutant in the work atmosphere. In therapy, the side effects of absorbed corticosteroids may depend on the type of the drug administered. At the workplace, corticosteroid dust may represent a combination of more than one type of corticosteroids which may produce more intense adverse effects than those expected to result from therapy. Of course, environmental industrial hygiene measures, if applied, can moderate such effects.

The prevalence of ocular hypertension and glaucoma in the present study mounted to $25.00 \%$ of the studied groups. Compared to rates from a study by Mitchell et al. [9] to investigate the association between ever use of inhaled corticosteroids and elevated IOP or glaucoma in subjects with a glaucoma family history, our present rates are much higher. Open-angle glaucoma is expected to affect 1 in 200 of the general population. In Mitchell's study, ocular hypertension affected $4.37 \%$ of patients while glaucoma affected $2.95 \%$ of them, with overall rate of $7.33 \%$. So, the occupational exposure clearly resulted in prevalence rates of ocular hypertension and glaucoma which were much higher than rates in the general population or in patients on corticosteroids therapy.

Increased IOP induced by corticosteroids may occur due to diminished outflow facility as a result of increased hyaluronic acid content of endothelial lining cells due to the steroid induced change in lysosomal membrane of goniocytes in the meshwork (Opatowsky et al. [11]). No family history was reported by any of the glaucoma cases in the present study. Failure to elicit positive family history may be due to lack of knowledge of the morbid condition among other family members or the presence of co-morbid medical disorders which masked the morbid condition leading to missed diagnosis and underreporting. However, lack of family history - if true - may signify that the occupational exposure to corticosteroids pollutants was intense and consistent enough to induce ocular hypertension and glaucoma irrespective of family history as a potent risk factor for this medical disorder as denoted by Mitchell et al. [9]. Other medical disorders which may be attributed to excess exposure to cortisone were more prevalent in the Group II of exposed workers as hypertension, diabetes mellitus, hyperacidity and headaches with an evident exposure gradient. These disorders, specifically diabetes mellitus, might have attributed to the occurrence of ocular manifestations among the exposed groups. Further research work is needed to study the effects of exposure to corticosteroids as pollutants in the work atmosphere, gaining access into body via multiple routes of entry, and for periods of time not reported in the therapeutic literature. Intervention strategies should be evaluated to minimize hazards and risks. Periodic full ocular examination of susceptible workers should 
be carried out for the early detection of medical disorders before irreversible complications set in.

\section{References}

[1] Carnahan MC, and Goldstein DA. Ocular complications of topical, periocular, \& systemic corticosteroids. Curr Opin Ophthalmol 2000; 11(6):478- 483.

[2] Davies DS. Pharmacokinetics of inhaled substances. Post-grad Med j 1975; 51 (Suppl 7): 69- 75.

[3] Dryer EB. Inhaled steroid use and glaucoma 'letter'. N Engl J Med 1933; 329: 1822.

[4] Fraunfelder FT, and Meyer SM. Posterior subcapsular cataracts associated with nasal or inhalation corticosteroids. Am J Ophthalmol 1990; 109: 489- 490.

[5] Garbe E, Suissa S, and LeLorier J. Association of inhaled corticosteroids with cataract extraction in elderly patients. JAMA 1998; 280: 539- 543.

[6] Haimovici R, Gragoudas ES, Duker JS, Sjaarda RN, and Eliott D. Central serous chorioretinopathy associated with inhaled or intranasal corticosteroids. Ophthalmology 1997; 104 (10): 1653- 1660.

[7] Khan HA, Leibowitz HM, and Ganley JP. The Framingham Eye Study: Outline and major prevalence findings. Am J Epidemiol 1977; 106: 1727.

[8] Leske MC, Chylack LT, and Wu SY. The lens opacities - case control study. Risk factors for cataract. Arch Ophthalmol 1991; 109: 244.

[9] Mitchell P, Cumming RG, and Mackey DA. Inhaled corticosteroids, family history, and risk of glaucoma. Ophthalmology 1999; 106 (12): 2301- 2306.

[10] Newman SP, Moren F, \& Pavia D. Deposition of pressure suspension aerosols inhaled through extension devices. Am Rev Respir Dis 1981;124: 317- 320 .

[11] Opatowsky I, Feldman RM, Gross R, and Feldman ST. Introcular pressure elevation associated with inhalation and nasal corticosteroids. Ophthalmology 1995; 102 (20):177- 179.

[12] United States Pharmacopeial Convention. Drug information for the health care professional, $12^{\text {th }}$ ed. Rockville, MD: US Pharmacopeial Convention 1992; 56- 62.

[13] West SK. Editorial: who develops cataracts? Arch Ophthalmol 1991; 109: 196. 